\title{
Kelas Menengah Santri \\ Dan Proses Demokratisasi di Indonesia
}

\author{
Agus Darmaji \\ UIN Syarif Hidayatullah Jakarta \\ agus.darmaji@uinjkt.ac.id
}

Abstract: The theory of the relationship between the middle class and democratization has been a serious discussion since the latter half of the 1950s when Martin Lipset tried to examine the relationship between the two to find out the main requirements for the realization and maintenance of democracy in a country. Since the Lipset period, the debate on the relation between the middle classdemocratization can be divided into two mainstream approaches, namely unilinear and contingent.

The first group that uses a unilinear approach has a theoretical basis for the theory of modernization. This group argues that when modernization occurs in a society, the level of income, education, socioeconomic mobility, and views on the values of freedom will also increase. These things are in turn believed to encourage the creation of democratization in a society or country that is not yet democratic, and at the same time can strengthen democratic institutions in countries that have implemented democracy as their state system. Hattori concluded that the presence of the middle class generally encouraged, even they became the main pillars of the movement towards democratization. In simple terms this unilinearist group wants to say that modernization in the socioeconomic sector will foster the middle class, which in turn will spearhead the realization of democratization in an undemocratic country. In short, according to this group the middle class is a major supporter of democratization and democracy in a country.

The second mainstream is those who use a contingent or conditional approach. Unlike the first group which considers the causal linearity between social classes as a consequence of modernization and democratization, this second group assumes that the relationship between the middle class and democratization is actually a more dynamic relationship. Bruce Dickson, for example, argues that "democratization is not a natural consequence of class changes due to economic growth. It is more a result of a political process that is colored by conflict, negotiation, where in some cases it results in the opposite condition, "for example returning to authoritarianism.

\section{Katakunci: Kelas Menengah Santri, Demokratisasi, Unilinier, Contingent}




\section{A. Pendahuluan}

Literatur mengenai hubungan kelas menengah dan demokratisasi sudah sangat banyak. Studi kelompok yang berpangkal pada teori modernisasi dan berpandangan uniliniear atas masalah kelas menengah dan demokratisasi terutama telah dibuktikan lewat studi politik sejak 1950-an di mana banyak dibahas soal peran kelas menengah pada periode transisi menuju atau dalam rangka memelihara demokrasi, terutama di dunia Barat. Beberapa karya dan penelitian yang mendukung teori ini dapat disebutkan misalnya Lipset pada $(1959)^{1}$ dan (1981)²; Nie, Powell, dan Prewitt (1969) 3 ; Dahl (1971) ${ }^{4}$; Milbrath (1977); Glassman (1995)5; Walsh, Jennings dan Stoker (2004). Pada umumnya, mereka berkesimpulan bahwa kelas menengah pada umumnya cenderung mendukung prinsip-prinsip demokrasi dan kemudian melakukan tindakan-tindakan yang dapat mendukung sekaligus menjaga berjalannya sistem pemerintahan yang demokratis, dan sebaliknya menentang sistem yang tidak demokratis.

Sedangkan pendekatan lain yang beranggapan bahwa hubungan kelas menengah-demokratisasi tidak linear, melainkan kondisisional (contingent) biasanya merujuk pada karya dan penelitian dari para ilmuwan semisal Johnson (1985); Stephens (1989); Rueschemeyer, Stephens dan Stephens (1992); Bertrand (1998); Hsiao dan Koo (1997); Brown dan Jones (1995); Acemoglu dan Robinson (2000); Englehart (2003); Hattori dan Funatsu (2003); dan Thompson (2004); serta Jie Chen dan Chunlong Lu (2011). Pandangan kelompok ini telah mendapatkan bukti terutama dari kajian kelas menengah di Dunia Ketiga atau negara-negara yang sedang berkembang, utamanya lagi kajian tentang negara-negara yang mengalami pertumbuhan ekonomi sangat tinggi. Mayoritas dari studi-studi tersebut menemukan bahwa kelas menengah memiliki posisi yang berbeda-beda dalam hal orientasinya terhadap demokratisasi. Perbedaan-perbedaan tersebut terutama merupakan akibat dari posisi hubungan mereka dengan kekuasaan, evaluasi mereka atas kehidupan sosial dan ekonomi, dan ketakutan atas perubahan stabilitas politik.

Perbedaan temuan di beberapa wilayah misalnya diperlihatkan oleh studi kelas menengah di Amerika Latin yang dilakukan Rueschemeyer, Stephens dan Stephens pada (1992) dan studi yang dilakukan Koo (1991); Brown and Jones (1995); Englehart( 2003); dan Jie Chen dan Chunlong Lu (2011) di wilayah Asia Timur dan Tenggara di mana kelas menengah terlihat mendukung demokratisasi pada saat dan di beberapa negara tertentu tetapi di waktu dan negara lain mereka malah cenderung mendukung keberlangsungan rezim otoriter. Di China, sebagaimana studi Jie Chen dan Chunlong Lu (2011), kelas 
menengah malah terlihat lebih mendukung rezim otoriter karena misalnya mereka merasa lebih diuntungkan oleh rezim tersebut secara politik dan ekonomi, bahkan sampai pada pendidikan dan karir mereka di dunia kerja.

Kajian soal Islam dan demokrasi di dunia Barat pada umumnya tidak menemukan adanya korelasi kuat antara keduanya, bahkan cenderung bertolak belakang. Untuk hal ini, bisa dilihat misalnya pada kajian yang dilakukan oleh Kedouri (1992), Huntington (1997), dan Lewis (2002), untuk menyebut beberapa di antaranya. Namun demikian, kajian kualitatif yang dilakukan oleh Fachri Ali dan Bachtiar Effendy (1992) dan Bachtiar Effendy (1998) memperlihatkan bahwa kelas menengah Muslim dan demokratisasi memiliki hubungan yang cukup kuat, setidaknya terpotret dari Kasus Indonesia yang dimulai sejak pertengahan periode Orde Baru sampai masa Reformasi. Rangkaian penelitian kuantitatif Saiful Mujani (2007) tentang Islam dan demokratisasi pasca-Reformasi yang kemudian menjadi Disertasi doktoralnya di Ohio State University, meski tidak secara khusus mengkaji kelas menengah Muslim dalam hubungannya dengan demokratisasi, misalnya menemukan bahwa peningkatan religiositas kelompok Muslim Indonesia tidak malah mengurangi dukungan mereka terhadap demokrasi dan demokratisasi. Sebaliknya, temuan Mujani mengungkap bahwa di Indonesia eskalasi religiositas kaum Muslim tampak berbanding lurus dengan dukungan mereka terhadap demokrasi. Artinya, mereka semakin takwa dan pada saat yang sama dukungan mereka terhadap demokrasi juga tetap tinggi.

\section{B. Kelas Menengah dan Demokrasi}

Teori tentang hubungan antara kelas menengah dan demokratisasi sudah menjadi perbincangan serius sejak paruh akhir dekade 1950-an ketika Martin Lipset (1959) coba menguji hubungan keduanya untuk mengetahui persyaratan utama untuk terwujud dan terpeliharanya demokrasi di sebuah negara. Sejak periode Lipset itu, perdebatan relasi kelas menengahdemokratisasi minimal dapat dibagi ke dalam dua mainstream pendekatan, yaitu unilinear dan contingent.

Kelompok pertama yang menggunakan pendekatan unilinear memiliki basis teoritik pada teori tentang modernisasi. Kelompok ini berpendapat bahwa ketika modernisasi terjadi pada sebuah masyarakat, maka taraf pendapatan, pendidikan, mobilitas sosioekonomi, dan pandangan tentang nilai-nilai kebebasan juga akan meningkat. Hal-hal tersebut pada gilirannya dipercaya akan mendorong terciptanya demokratisasi di masyarakat atau negara yang belum demokratis, sekaligus dapat memperkuat lembaga-lembaga demokratis di 
negara yang memang sudah menerapkan demokrasi sebagai sistem kenegaraannya. Hattori dkk. menyimpulkan bahwa kehadiran kelas menengah pada umumnya mendorong, bahkan mereka menjadi pilar utama dari, gerakan menuju demokratisasi. Secara sederhana kelompok unilinearis ini ingin mengatakan bahwa modernisasi di sektor sosioekonomi akan menumbuhkan kelompok kelas menengah, yang pada gilirannya akan menjadi ujung tombak dari perwujudan demokratisasi di negara yang belum demokratis. Singkatnya, menurut kelompok ini kelas menengah adalah pendukung utama dari demokratisasi dan demokrasi di sebuah negara. ${ }^{6}$

Mainstream kedua adalah mereka yang menggunakan pendekatan contingent atau kondisional. Berbeda dengan kelompok pertama yang menganggap adanya linearitas sebab akibat antara kelas sosial sebagai konsekuensi modernisasi dengan demokratisasi, kelompok kedua ini beranggapan bahwa hubungan antara kelas menengah dan demokratisasi sesungguhnya adalah relasi yang lebih berifat dinamis. Bruce Dickson ${ }^{7}$, misalnya, berpendapat bahwa "demokratisasi bukanlah merupakan sebuah konsekuensi alamiah dari perubahan kelas akibat pertumbuhan ekonomi. Ia lebih merupakan hasil dari proses politik yang diwarnai oleh konflik, negosiasi, di mana pada beberapa kasus malah menghasilkan kondisi sebaliknya," misalnya kembali ke otoritarianisme.

\section{Islam, Demokrasi, dan Peran Kaum Santri}

Di dunia Islam, para ahli Ilmu politik kebanyakan berkesimpulan bahwa Islam tidak kompatibel dengan demokrasi (Kedouri; Huntington; dan Lewis). Maka dapat ditarik kesimpulan bahwa kelas menengah kelompok Islam tidak berkontribusi signifikan pada penguatan demokratisasi. Meski belakangan perkembangan sebaliknya kemudian dijumpai pada penelitian di beberapa negara. Di Indonesia sendiri, trikotomi pengelasan masyarakat ke dalam priyayi, santri, dan abangan yang diajukan Clifford Geertz (1976) memang berpengaruh cukup kuat dalam kajian antropologi, sosiologi, bahkan politik. Namun, ia juga menuai kritik dari banyak kalangan, dan karenanya terus mengalami perkembangan. Golongan priyayi identik dengan masyarakat kelas atas, meski ini masih bisa diperdebatkan. Sementara santri dan abangan bisa terdiri mulai dari kelas bawah sampai kelas atas. Perdebatan soal kelas menengah di Indonesia kemudian hampir tidak menemui titik simpul yang jelas. Hal ini akan makin problematis, misalnya, dengan kemunculan istilah budaya kelas menengah (middle class culture) yang kemudian melahirkan kelompok kelas menengah baru dalam literatur kelompok keislaman di Indonesia. Aswab Mahasin (1993) 
misalnya menyebut kelompok baru ini sebagai kelas menengah santri yang memiliki social origin campuran antara keluarga priyayi di satu pihak, dan keluarga petani kaya dan pedagang kecil ekonomi bazar di pihak lain, di mana mayoritas mereka berlatar belakang keluarga santri.

Kelompok baru ini pada gilirannya berperan cukup strategis dalam perubahan dan perkembangan konsepsi kenegaraan di Indonesia. Harry J. Benda (1980) pernah menyatakan bahwa pada masa kolonialisme Jepang, kemunculan kaum santri kota setidaknya berperan dalam perjuangan untuk mengubah formalisme kolot, kebudayaan adat dan priyayi, dan status quo penjajahan. Nyaris serupa dengan kondisi tersebut, kemunculan generasi kelas menengah santri sejak periode Nurcholish Madjid juga berperan dalam gerakan reformasi pemahaman teologi Islam, budaya dan politik, sampai gerakan Reformasi 1998 yang akhirnya menumbangkan rezim otoriter Soeharto (Effendy, 2009). Penjelasannya, kelompok baru ini berkontribusi terhadap perkembangan ide-ide pluralisme, sekularisme dan liberalisme yang pada gilirannya menjadi pilar dari proses demokratisasi yang berjalan di Indonesia.

Pada titik lain, Penelitian kuantitatif Saiful Mujani yang kemudian dibukukan dengan judul Muslim Demokrat (2007) malah menyimpulkan bahwa semakin takwa seorang Muslim di Indonesia tidak serta merta membuat mereka semakin berseberangan dengan nilai-nilai demokrasi, sebagaimana sebelumnya di klaim Samuel Hantington dan lain-lain. Sebaliknya temuan Mujani malah kurang lebih menyimpulkan bahwa ketakwaan kalangan Islam di Indonesia justru dapat membuat mereka malah supportif terhadap ide dan praktik demokratisasi dan demokrasi. Pada konteks ini, peran kelas menengah santri di Indonesia, terutama mereka yang beraktivitas di bidang pendidikan, politik dan bergiat di lembaga-lembaga swadaya masyarakat yang memperjuangkan hak asasi manusia dan nilai-nilai demokrasi, dipercaya cukup berkontribusi untuk perkembangan dan penguatan konteks kini negeri ini. Secara garis besar, oleh karenanya dapat disimpulkan bahwa terdapat hubungan yang cukup kuat antara kehadiran kelas menengah santri dan perkembangan demokratisasi di Indonesia.

\section{Partisipasi Politik sebagai Peran Warga dalam Konsolidasi Demokrasi}

Herbert, seperti dikuti oleh Mariam Budiarjo, mendefenisikan konsep partisipasi politik sebagai kegiatan-kegiatan sukarela dari warga masyarakat tentang bagaimana mereka mengambil bagian dalam proses pemilihan penguasa, dan secara langsung ataupaun tidak langsung, dan dalam proses pembuatan kebijakan umum. Partisipasi dapat dilakukan secara individu 
maupun bersama-sama, terorganisir dan spontanitas, terus menerus atau sporadis, secara damai atau kekerasan, legal atau ilegal, efektif maupun tidak efektif. ${ }^{8}$

Ada 2 (dua) macam partisipasi politik berdasarkan cara keterlibatannya: partisipasi langsung dan partisipasi tidak langsung. Partisipasi langsung terjadi jika individu menampilkan kegiatan tertentu dalam proses partisipasi. Partisipasi langsung terjadi manakala setiap orang dapat mengajukan pandangan, membahas pokok permasalahan, mengajukan keberatan terhadap keinginan orang lain atau terhadap ucapannya. Adapun partisipasi tidak langsung terjadi apabila individu mendelegasikan hak partisipasinya.

Adapun Cohen dan Uphoff, seperti dikutip oleh Siti Irene Astuti, membedakan partisipasi menjadi empat jenis: pertama, partisipasi dalam pengambilan keputusan; partisipasi dalam pelaksanaan, partisipasi dalam pengambilan pemanfaatan, dan partisipasi dalam evaluasi ${ }^{9}$. Menurut Merphin Panjaitan, demokrasi berhubungan dengan partisipasi politik masyarakat. Semakin tinggi partisipasi politik masyarakat, maka semakin tinggi kadar demokrasi negara tersebut ${ }^{10}$.

\section{Faktor-faktor yang Mempengaruhi Partisipasi Warga dalam Konsolidasi Demokrasi}

Yang menjadi fokus dalam tulisan ini adalah variabel-variabel apa yang menentukan masyarakat sipil aktif berpartisi dalam proses demokratisasi. Ada beberapa teori yang menunjukan variabel-variabel yang menentukan. Dari beberapa teori, berikut hal-hal yang menjadi variabel dalam tingkat partisipasi warga negara dalam proses demokratisasi.

\section{a. Pendidikan}

Pendidikan merupakan satu faktor penting yang menentukan keputusan warganegara terlibat aktif dalam konsolidasi demokrasi. Karena melalui pendidikan terjadi peningkatan pengetahuan umum seseorang termasuk di dalamnya dengan peningkatan penguasaan teori dan keterampilan memutuskan terhadap persoalan yang menyangkut kegiatan mencapai tujuan. Olah karena itu pendidikan tinggi dapat memberikan informasi tentang politik dan persoalan-persoalan politik dapat juga dengan mengembangkan kecakapan dalam menganalisa menciptakan minat dan kemampuan dalam berpolitik. Untuk itu, pendidikan menjadi salah satu faktor yang dapat memengaruhi 
seseorang ataupun masyarakat dalam mengambil keputusan dalam pemilihan umum, dan mempengaruhi partisipasi politik. ${ }^{11}$

Penjelasan Collin dan Mas'oed ini secara eksplisit mengatakan bahwa semakin tinggi tingkat pendidikan maka semakin aktif berpartispasi dalam berpolitik dan konsolidasi demokrasi karena modal pengetahuan. Teori ini terbukti dalam sebuah hasil penelitan Lingkaran Survei Indonesia (LSI) yang meneliti tingkat partisipasi warga DKI Jakarat dalam Pilkada 2007. Demografi pemilih dengan tingkat pendidikan $S 1$ ke atas hanya terdapat $12,6 \%$ yang tidak memilih. Adapun lulusan SMA menembus angka 40,2\%, disusul lulusan SD $25,2 \%$ dan lulusan SMP 22,0\%. ${ }^{12}$

\section{b. Tingkat Ekonomi}

Alasan warga negara ikut berpartisipasi dalam kehidupan politik adalah adanya kepuasan finansial. Lindenfield pun menyatakan bahwa status ekonomi yang rendah menyebabkan seseorang merasa teralienasi dari kehidupan politik. Dan orang yang bersangkutan pun akan menjadi apatis. Hal ini tidak terjadi pada orang yang memiliki kemapanan ekonomi.

Tingkat ekonomi masyarakat sendiri secara umum terbagi menjadi tiga kelas, yakni: kelas atas, menengah, dan bawah. Untuk lebih memudahkan pendefinisian tiga kelas tersebut, baiknya melihat bagaimana World Bank mendefiniskan kelas menengah. Ada tiga pendekatan untuk mendefinisikan kelas menengah berdasarkan pengeluaran atau pendapatan rumah tangga: (i) pendekatan absolut, (ii) pendekatan relatif, dan (iii) pendekatan gabungan. Pendekatan absolut mendefinisikan kelas menengah pada tingkat pengeluaran tertentu; mereka yang memiliki penghasilan (atau menghabiskan) pada batas atas dan bawah tertentu dianggap sebagai kelas menengah. Pendekatan relatif menekankan pada tingkat pendapatan atau pengeluaran rumah tangga secara relatif terhadap yang lain. Angka persentase pengeluaran per kapita seringkali digunakan untuk pendekatan relatif. Pendekatan gabungan merupakan campuran dari pendekatan absolut maupun relatif. ${ }^{13}$

Tulisan ini menggunakan pengukuran absolut, mengidentifikasi kategori kelas menengah berdasarkan standar World Bank, yang disesuaikan dengan pendekatan Bank Pembangunan Asia, di mana kelas 
menengah didefinisikan sebagai mereka dengan pengeluaran harian per kapita antara 2 dolar Amerika dan 20 dolar Amerika ${ }^{14}$.

Berdasarkan definisi di atas, maka seseorang masuk dalam kategori kelas menengah ketika pengeluarannya hariannya sekitar 2 dolar atau sekitar Rp.26,000 (Kurs 13 ribu rupiah/1 \$ USA) hingga 20 dolar atau Rp.260,000. Adapun kelas ekonomi bawah pengeluarn perharinya di bawah 2 dolar dan kelas atas di atas 20 dolar perhari. Lalu bagaimana tiga kelas ini dalam partisipasi konsilidasi demokrasi?

Bahwa ada pandangan umum bahwa kelas menengah memiliki pengaruh besar dalam demokrasi, yang merujuk pada kata bijak Aristoteles: "tidak ada kelas menengah, tidak ada demokrasi." Pandangan ini mapan dirawat dan dikembangkan dalam teori-teori gerakan sosial dan politik. Namun hasil riset Elizabeth J. Zeichmester, dkk. di Amerika Latin, menemukan bahwa tak ada perbedaan presentase signifikan dalam kepedulian kelas menengah terhadap partisipasi politik dibanding kelas di atas dan kelas di bawahnya ${ }^{15}$.

\section{c. Tingkat Kemudahan Akses Informasi}

Masyarakat modern tidak bisa terlepas dari media informasi, seperti televisi, koran, radio dan internet. Media-media informasi tersebut menjadi sarana masyarakat untuk mengakses informasi dari segala bidang, pun tentang perkembangan politik dan pemerintahan. Negara demokrasi memiliki salah satu indikator yakni kebebasan pers. Pers yang bebas dan independen serta kemampuan masyarakat dalam mengakses informasi menjadi prasyarat berjalannya proses demokratisasi kearah yang lebih baik.

Mendapatkan informasi dengan mudah adalah modal bagi masyarakat untuk mengetahui kondisi sosial, ekonomi dan politik di negaranya dengan baik, yang menjadi pra-asumsi untuk menentukan sikap dalam berpolitik. ${ }^{16}$ Dengan banyak mengetahui informasi, masyarakat bisa terdorong untuk melakukan apa yang perlu mereka perbuat dengan tepat sebagai warga negara, merujuk pada informasiinformasi yang ia dapat. Baik melalui komentar, protes, dukungan atau penolakan pada isu-isu tertentu, ataupun keberpihakan pada satu kekuatan politik tertentu.

Mengakses informasi politik, dalam penelitan yang dilakukan oleh Eteng Uwe dan Opeke, yang berfokus pada partisipasi perempuam dalam politik di Nigeria; menemukan hasil bahwa seberapa sering 
mengakses informasi-informasi politik mempengaruhi bagaimana perempuan di Nigeria turut aktif mendukung kepentingan kaum perempuan di negaranya. Dalam kata lain, jarang atau tidak pernah mengakses informasi memungkinkan warganegara demorasi tidak tahu apa yang harus ia lakukan dalam mendukung kebaikan kepentingan pribadinya atau kelompoknya. ${ }^{17}$

\section{d. Tingkat Kepuasan terhadap Pelayanan Publik}

Pelayanan publik, menurut pasal 1 Undang-Undang Pelayanan Publik, diartikan sebagai kegiatan atau rangkaian kegiatan dalam rangka pemenuhan kebutuhan pelayanan sesuai dengan peraturan perundangundangan bagi setiap warga negara dan pendudukan atas barang, jasa, dan/atau pelayanan administrasi yang disediakan oleh penyelenggara pelayanan publik.

Terdapat 10 bidang pelayanan publik, yakni: administrasi kependudukan, pendidikan, kesehatan, transportasi, ketenagakerjaan, industri, perdagangan, ekonomi dan keuangan, hukum dan Hak Asasi Manusia (HAM), dan keamanan.

Pengalaman mendapat kepuasan bagi warganegara terhadap pelayan publik menciptakan tingkat kepercayaan yang baik bagi warganegara terhadap pemerintah sebagai pihak penyelenggara pelayanan publik. Kepercayaan ini menjadikan warganegara mensupport terhadap proses dan hasil dari kebijakan-kebijakan ${ }^{18}$.

Dalam tingkat kepercayaan yang baik masyarakat terhadap pemerintah, menciptkan kolaborasi keduanya, di mana masyarakat sipil dan organisasi masyarakat bersama pemerintah menciptakan dan merawat good governance dan sistem demokrasinya dengan mengimplementasikan kebijakan-kebijakan dan hukum yang ada, aktif menjadi masyarakat yang taat hukum dan pajak, dsb. ${ }^{19}$

\section{e. Tingkat Kepercayaan terhadap Institusi-institusi Demokrasi}

Kepercayaan pada institusi-institusi demokrasi dapat memengaruhi peran warga negara untuk terlibat dalam proses demokratisasi. Institusi-institusi demokrasi ada lima kategori. Pertama, lembaga eksekutif, yang mencakup Pemerintah Pusat, Pemerintah Provinsi, dan Pemerintah Kabupaten/Kota. Kedua, lembaga legislatif, yang mencakup Dewan Perwakilan Rakyat (DPR), Dewan Perwakilan Daerah (DPD), Dewan Perwakilan Rakyat Daerah (DPRD) Provinsi, 
dan DPRD Kabupaten/Kota. Ketiga, lembaga yudikatif, yang meliputi Mahkamah Konstitusi dan Mahkamah Agung. Keempat, lembaga masyarakat, terdiri dari Lembaga Swadaya Masyarakat (LSM) dan Organisasi Masyarakat (Ormas) Keagamaan. Dan, kelima, media massa, yang dirinci menjadi surat kabar cetak, stasiun televisi, stasiun radio, dan situs berita online.

Menurut Levi dan Stoker, seperti dikutip oleh Sang Ok Choi, kepercayaan yang baik warganegara terhadap institusi pemerintah dapat meningkatkan aktivitas-aktivitas politik warganegara, seperti turut dalam pemilu. Juga, warganegara siap mendukung secara aktif terhadap kebijakan-kebijakan pemerintah dan struktur pemerintahan ${ }^{20}$.

Teori tersebut dipatenkan dengan temuan penelitan literatur oleh Sang Ok Choi dan Sunhyuk Kim, di mana masyarakat sipil dan organisasi masyarakat bersama pemerintah yang dapat dipercaya menciptakan kolaborasi keduanya dalam merawat good governance dan sistem demokrasinya dalam bentuk pengimplementasian kebijakankebijakan dan hukum yang ada, dan menjadi masyarakat yang taat hukum dan taat pajak, dsb. ${ }^{21}$

\section{f. Akses terhadap Sumber Daya Politik}

Variabel lain yang juga mempengaruhi partisipasi warga dalam proses demokratisasi ialah kemudahan mengakses sumber daya politik, yaitu institusi-institusi dan individu-individu dalam masyarakat yang dapat digunakan oleh warga dalam rangka mempengaruhi proses politik dan pengambilan kebijakan.

Partai Politik (Parpol) dan Lembaga Swadaya Masyarakat (LSM) merupakan sumber daya politik dalam bentuk institusi, sedangkan pengurus Papol dan aktivis LSM merupakan sumber daya politik dalam bentuk individu.

Pasal 11 Undang-Undang Nomor 2 Tahun 2008 tentang Partai Politik (UU Parpol) mengatakan bahwa fungsi Partai Politik sebagai sarana: (a) pendidikan politik bagi anggota dan masyarakat luas agar menjadi warganegara Indonesia yang sadar akan hak dan kewajibannya dalam kehidupan bermasyarakat, berbangsa, dan bernegara; dan (d) partisipasi politik warga negara Indonesia.

Melihat dua fungsi partai politik tersebut, maka jelas bahwa kemudahan masyarakat untuk mengakses partai politik dapat menentukan sikap lebih partisipatif dalam proses konsolidasi demokrasi. 
Hal ini karena partai politik sebagai wadah bagi kepentingankepentingan anggotanya dapat mengelola tujuan bersama secara terorganisir, sehingga muncul kepastian.

Namun meski demikian, fenomena turunnya angka partisipasi politik masyarakat dalam pemilu 2009, yang disertai meningkatnya Golput yang cukup signifikan, terutama pada penyelenggaraan pemilu di era reformasi sebagai era transisi demokrasi tersebut tentunya memiliki alasan kondisional, antara lain karena kinerja partai politik yang dipandang oleh publik gagal memperjuangkan aspirasi masyarakat, melainkan mereka lebih fokus mengejar kekuasaan demi kepentingan partai atau elite politik. ${ }^{22}$

Seperti halnya partai politik, LSM juga menjadi wadah penting bagi masyarakat untuk menyampaikan aspirasinya secara terorganisir. Berdasarkan penelitian tentang peran masyarakat sipil dalam proses demokratisasi, LSM memiliki peran yang cukup baik dalam mengadvokasi masyarakat untuk turut berpartisipasi dalam konsolidasi demokrasi, dan melakukan pengawasan terhadap pemerintah ${ }^{23}$.

Kemudahan masyarakat untuk mendapatkan sosialisasi, pendampingan dan advokasi tentang politik, secara tidak langsung memengaruhi tingkat partisipasi masyarakat dalam konsolidasi demokrasi, karena LSM memiliki peran pengawasan dan pendidikan partisipasi politik kepada masyarakat.

\section{g. Ideologi}

Ideologi juga memiliki pengaruh dalam tingkat partisipasi politik dalam demokrasi. Semakin liberal nilai-nilai ideologi yang dianut warga, semakin besar perannya dalam demokrasi. Juga sebaliknya, semakin konservatif nilai-nilai ideologi yang diantut warga, semakin kecil perannya dalam demokrasi.

Ideologi liberal dapat diukur dalam bagaimana sikap individu terhadap hak warga dari kelompok minoritas etnis/suku, agama/keyakinan, dan hak difabel untuk menempati jabatan-jabatan publik dan penyelenggaraan pemerintahan pada berbagai level.

Warga yang berideologi liberal cenderung berpikiran terbuka dibanding warga yang konservatif ${ }^{4}$, sehingga cara pandang liberal terhadap orang yang berbeda atau kalangan minoritas, menilainya sebagai individu yang setara. Cara pandang seperti ini menentukan sikap partisipasi dalam demokrasi, karena mereka memiliki perhatian 
lebih kepada keragaman kelompok dibanding individu yang berideologi konservatif atau fundamentalis. Meski demikian, belum ada penelitian yang secara spesifik membantah dan memantapkan teori tersebut.

\section{h. Deprivasi Relatif}

Istilah deprivasi relatif menurut Sttoufler menekankan pada pengalaman individu dan kelompok dalam kondisi kekurangan dan tidak beruntung. Selanjutnya konsep ini dikembangkan oleh Davis dan didefinisikan sebagai persepsi terhadap adanya perbedaan antara kenyataan dan harapan atau keinginan ${ }^{25}$.

Deprivasi relatif menjadi salah satu teori gerakan sosial, dalam mendorong seseorang atau kelompok melakukan protes maupun demonstrasi. Menurut Ted Robert Gurr dalam bukunya Why Men Rebel (1970), ide dasar teori ini adalah adanya "penghilangan", "perampasan", yang disertai ketegasan dan keterusterangan dalam penolakannya itu sebagai suatu respon terhadap suatu ketidakadilan yang mereka rasakan $^{26}$.

Secara lebih rinci bahwa dalam teori deprivasi relatif ini; (1) depvrivasi relatif sebagai perubahan harapan dan kemampuan untuk memenuhi harapan itu, maka bentuk deprivasi dapat dibedakan berdasarkan pola-pola perubahan; (a) deprivasi persisten; yaitu kemampuan yang secara konstan berada di bawah harapan; (b) deprivasi aspirasional; yaitu harapan naik kemampuan konstan; (c) deprivasi dekremental; di mana harapan konstan dan kemampuan turun; (d) deprivasi progresif; di mana kemampuan naik tetapi masih lebih rendah dibandingkan harapan. Namun yang paling menentukan dalam munculnya gerakan dan kekerasan politik adalah faktor "ketidakpuasan". (2) Ada tiga bentuk faktor yang memperantarai gerakan dan kekerasan politik; (a) justifikasi normatif untuk kekerasan; (b) justifikasi kemanfaatan untuk kekerasan; (3) keseimbangan antara sumber-sumber daya koersif dan institusional dari pemberontak vs negara $^{27}$.

Dapat ditangkap dari penjelasan di atas bahwa deprivasi relatif memiliki pengaruh terhadap gerakan sosial, dalam hal ini partisipasi warganegara dalam melakukan protes dalam bentuk demonstrasi, dan lain-lain. 


\section{Kerangka Konseptual}

Kerangka konseptual atau kerangka pikir merupakan model konseptual tentang bagaimana teori berhubungan dengan berbagai faktor yang telah diidentifikasikan. Bagian ini membahas konsep-konsep utama: kelas menengah, santri, kelas menengah santri, dan demokratisasi.

\section{Kelas Menengah}

Kelas menengah sebagai kelas sosial memang tidak melulu diukur secara kuantitatif dengan indikator pendapatan dan pengeluaran semata, tapi juga diukur dengan tingkat pendidikan, status profesi, gaya hidup, dsb. Meski demikian, faktor ekonomi menjadi variabel utama dalam menentukan kategori kelas menengah. Lebih spesifik, kelas menegah dilihat dari tingkat pengeluaran rumah tangga secara agregat.

Ada tiga pendekatan untuk mendefinisikan kelas menengah berdasarkan pengeluaran atau pendapatan rumah tangga: (i) pendekatan absolut, (ii) pendekatan relatif, dan (iii) pendekatan gabungan. Pendekatan absolut mendefinisikan kelas menengah pada tingkat pengeluaran tertentu; mereka yang memiliki penghasilan (atau menghabiskan) pada batas atas dan bawah tertentu dianggap sebagai kelas menengah. Pendekatan relatif menekankan pada tingkat pendapatan atau pengeluaran rumah tangga secara relatif terhadap yang lain. Angka persentase pengeluaran per kapita seringkali digunakan untuk pendekatan relatif. Pendekatan gabungan merupakan campuran dari pendekatan absolut maupun relatif. ${ }^{28}$

\section{Santri}

Kata "santri" berasal dari bahasa tamil yang berarti "guru mengaji". Sedangkan C.C Berg, seperti dikutip oleh Zamakhsyari, berpendapat bahwa istilah santri berasal dari kata "shastri", yang dalam bahasa India berarti "orang yang mengetahui buku-buku suci agama Hindu". Pendapat ini didukung oleh Karel. A. Steenbrink, yang menyatakan bahwa pendidikan pesantren, dilihat dari segi bentuk dan sistemnya, memang mirip dengan pendidikan ala Hindu di India ${ }^{29}$.

Pendapat lain mengatakan bahwa kata "santri" berasal dari kata "sastri" dalam bahasa Sansekerta, yang artinya "melek huruf” alias bisa membaca. Ada juga yang meneliti bahwa kata santri berasal dari bahasa Jawa, dari kata cantrik, yang berarti seseorang yang selalu mengikuti gurunya kemanapun gurunya pergi/menetap ${ }^{30}$. 
Berdasarkan penelusuran akar kata di atas, dapat disimpulkan bahwa santri adalah seseorang yang paham agama Islam karena berada dalam sistem pembelajaran di pondok pesantren sebagai peserta didik yang berguru ilmu agama Islam pada seorang atau beberapa orang guru atau kyai. Adapun santri, menurut Zamakhsyari Dzofier, dikelompokkan ke dalam dua kelompok. Pertama, santri mukim, yakni santri yang menetap di pesantren selama proses menyantri. Kedua, santri kalong, yakni santri atau peserta didik yang berasal dari daerah-daerah sekitar pesantren dan tidak bermukim di pesantren ${ }^{31}$.

Definisi santri memiliki 4 kata kunci: peserta didik, pondok pesantren, kyai, dan ilmu agama Islam. Untuk itu, seseorang disebut santri jika menjadi peserta didik di pondok pesantren yang berguru pada seseorang atau beberapa kyai untuk memperdalam ilmu agama Islam, baik sebagai santri mukim atau santri kalong.

\section{Kelas Menengah Santri}

Robert Heffner, seorang antropolog, melihat pada akhir 1970-an di Indonesia mengalami gelombang modernitas Islam. Heffner melihat bahwa proyek modernitas Islam kenyataannya juga berasal dari kalangan tradisional atau santri yang mencoba berafiliasi dengan berbagai lembaga agama modern dan lembaga sekular modern di sekitarnya. Ia menengarai pada masa itu masyarakat santri tradisional tengah berada dalam proses transformasi menjadi modern dengan bernegosiasi pada kekuasaan Orde Baru. Pada pertengahan masa kekuasaan Soeharto, santri tradisional mulai terdidik, ter-Barat-kan, dan bahkan santri mulai bergulat dengan dunia kapitalisme percetakan (penerbitan buku, jurnal, dan pamphlet) yang berbincang tentang siapa, apa, dan bagaimana santri melihat dunia dan permasalahannya. Heffner menyebut fenomena ini sebagai "printing Islam"32.

Gelombang modernisasi muslim-santri ini membawa pergeseran image santri dari konotasi kampungan dan kelas bawah ke image santri yang beradaptasi dengan perkembangan ekonomi, sosial, politik, dan budaya modernitas ini menjadikan banyak santri dan mantan santri secara kelas sosial menduduki kelas menengah dan menengah atas. Hal penting ini juga diikuti pada masa pasca-reformasi, di mana muslim lulusan pesantren banyak yang melanjutkan pendidikannya ke kampus-kampus Islam modern, seperti IAIN. Maka wajar jika saat ini, banyak sekali santri yang merupakan lulusan perguruan tinggi Islam ataupun sekuler, yang berkarir menjadi guru, pegawai negeri sipil, pekerja sosial, dan lain-lain. 
Melewati pendidikan tinggi dan mendapat pekerjaan yang layak menjadikan kaum santri saat ini memiliki pendapatan yang memadai untuk memenuhi standar kebutuhan atau gaya hidup mereka sebagai kelas sosial menengah atas. Pergesaran ini menjadikan santri menjadi kelas unik yang memiliki corak kultur islami namun mengikuti pola modernisasi yang diikuti dengan proses demokratisasi di Indonesia. Peran mereka pun diperhitungkan. Banyak dari kelas menengah santri itu aktif dalam politik praktis dan menjadi pekerja sosial, dan akademisi.

Apa yang disebut kelas menengah santri bukanlah apa yang Kuntowidjoyo sebut sebagai "Neo Santri" atau masyarakat muslim alim yang bertransformasi menjadi santri modern, dengan tanpa harus melewati masamasa pendidikan di pesantren ${ }^{33}$. Definisi santri kelas menengah merujuk pada penjelasan di atas dan definisi santri dan kelas menegah di dua sub-bab sebelumnya, di mana jika disimpulkan yang dimaksud santri kelas menengah adalah mereka yang pernah belajar atau menjadi peserta didik di pondok pesantren yang kemudian memiliki pendapatan layak dan pengeluaran per hari USD 5 hingga USD 10.

\section{Demokratisasi}

Demokrasi merupakan sistem pemerintahan rakyat berdaulat yang berbasis pada pengakuan hak sipil dan politik setiap individu warga untuk berpartisipasi dalam penyelenggaraan suatu pemerintahan. Demokrasi ditandai dengan pembagian kekuasaan secara seimbang antara eksekutif, legislatif, dan yudikatif, tersedianya kanal-kanal penyaluran aspirasi warga seperti Pemilihan Umum yang bebas, jujur, dan adil dan kebebasan pers, dan berkembangnya organisasi-organisasi masyarakat sipil.

Demokratisasi adalah proses perkembangan prosedur dan institusiinstitusi demokrasi. Dengan demikian, peran dalam demokratisasi adalah tingkah laku yang diharapkan dimiliki oleh individu pada posisi sosial tertentu di masyarakat yang dapat mendorong perkembangan prosedur dan institusiinstitusi demokrasi.

\section{Kesimpulan}

Salah satu kesulitan terbesar dalam mengidentifikasi kelas menengah santri dan bagaimana kelompok ini berperan dalam proses demokratisasi ialah tidak adanya suatu rumusan definitif yang disepakati tentang apa yang disebut "kelas menengah santri". Bahkan, harus diakui, "kelas menengah santri" adalah konsep yang cenderung digunakan secara longgar dalam sejumlah kajian 
terdahulu, baik dalam dimensi "ke-kelas menengah-an" maupun dalam dimensi "ke-santri-an".

Dalam dimensi "ke-kelas menengah-an", misalnya, kajian-kajian terdahulu cenderung mencampuradukkan berbagai ciri dalam apa yang mereka definisikan sebagai "kelas menengah". Di satu sisi, kelas menengah, misalnya, terlanjur dikesankan sebagai suatu kelompok dengan individu-individu yang mapan secara ekonomi, konsumtif dalam perilaku ekonomi, berpendidikan tinggi, dan mendukung demokrasi. Tidak diposisikan secara tegas mana di antara ciri-ciri ini yang bersifat esensial dan mana yang bersifat aksidental, mana yang niscaya dan mana yang mungkin.

Di sisi lain, kriteria-kriteria apa yang digunakan untuk menyebut seseorang mapan secara ekonomi, berpendidikan tinggi, dan mendukung demokrasi itu sendiri sering kali, secara sebagian atau keseluruhan, tidak dinyatakan secara tegas. Misalnya, atas ukuran apa seseorang disebut mapan secara ekonomi (apakah punya rumah sendiri dengan ukuran luas tanah dan bangunan tertentu, tidak punya hutang, memiliki kendaraan, berpendapatan dengan nilai nominal tertentu, daya beli?); pada tingkat pendidikan apa seseorang disebut berpendidikan tinggi (apakah SMA, pendidikan tinggi, S1, S2, S3?), gaya hidup konsumtif (apakah keragaman jenis-jenis barang/jasa yang dikonsumsi, nilai nominal konsumsi, banyak hutang?), dan sikap-sikap apa yang disebut mendukung demokrasi (apakah mendukung liberalisme, sosialisme, hak-hak minoritas, intensitas partisipasi politik?). Ketidaktegasan dalam kriteria-kriteria ini mengakibatkan berbagai kajian tentang peran kelas menengah dalam demokrasi berulang kali menunjukkan hasil yang bertentangan. Sangat besar kemungkinan, apa yang disebut sebagai "kelas menengah" oleh masing-masing kajian sesungguhnya adalah subyek-subyek dengan karakteristik yang sama sekali berbeda atau, minimal, tidak sepenuhnya sama.

Kegamangan serupa juga tampak dalam dimensi "kesantrian". Sebagian kajian mendefinisikan santri sebagai individu pemeluk agama Islam (Muslim) yang religius atau saleh, tanpa juga menyebut secara spesifik indikator-indikator kriteria yang digunakan untuk menyebut individu itu sebagai Muslim yang religius atau saleh (apakah ketaatan beribadah, kepercayaan pada hari akhir, rajin beramal?). Sebagian yang lain bahkan cenderung merancukan konsep "santri" dalam istilah "kelas menengah santri" dengan konsep "Muslim", sehingga istilah "kelas menengah santri" cenderung identik dengan "kelas menengah Muslim". Satu atau dua kajian memang menyinggung soal sebagian besar di antara kelas menengah santri memiliki latar belakang pendidikan 
pesantren. Kriteria yang tidak tegas ini membuka kemungkinan munculnya satu kategori yang aneh, yaitu "Muslim yang bukan santri". Sebagaimana dalam kasus konsep "kelas menengah", istilah "santri" dalam berbagai kajian terdahulu sangat mungkin menunjuk pada subyek-subyek penelitian yang berbeda.

Dari dimensi ekonomi, konsep "kelas menengah" harus dimengerti dalam posisinya sebagai strata yang berada di antara "kelas atas" dan "kelas bawah". Dari dimensi keagamaannya, konsep "santri" hanya dapat dimengerti dalam oposisinya dengan konsep "non-santri", yang meliputi "non-santri Muslim" dan "non-santri non-Muslim". Dengan menggunakan dimensi ekonomi dan dimensi keagamaan ini secara sekaligus pada aras vertikal dan horisontal, maka terdapat sembilan konsep kelompok sosial dalam masyarakat, yaitu (1) "kelas atas santri", (2) "kelas atas non-santri Muslim", (3) "kelas atas non-santri non-Muslim", (4) "kelas menengah santri", (5) "kelas menengah non-santri Muslim", (6) "kelas menengah non-santri non-Muslim", (7) "kelas bawah santri", (8) "kelas bawah non-santri Muslim", dan (9) "kelas bawah nonsantri non-Muslim”.

Terpetakannya posisi konseptual kelas menengah santri di antara kelompok-kelompok sosial lain tersebut memungkinkan dilakukannya pengumpulan dan analisis data secara jelas dan terpilah tentang berbagai kondisi kelas menengah santri dalam komparasinya dengan kelompok-kelompok sosial lain, misalnya, kelas menengah non-santri Muslim, kelas menengah non-santri non-Muslim, atau kelompok-kelompok sosial yang lain. Analisis tersebut mencakup tidak hanya variabel-variabel demografis seperti usia, jenis kelamin, tingkat pendidikan, dan sebagainya, tetapi juga variabel-variabel sikap seperti kepercayaan pada institusi-institusi demokrasi, ideologi, dan tingkat partisipasi politik.

Hal yang sama juga dapat dikatakan terkait ciri demografis tingkat pendidikan dari kelompok kelas menengah santri. Sebelumnya, tidak ada gambaran yang terbukti secara empiris tentang profil pendidikan kelas menengah santri. Orang berspekulasi tentang kelas menengah santri sebagai kelompok santri yang terdidik, tanpa menyebut seperti apa kondisi-kondisi terdidik tersebut. Hal ini menunjukkan kondisi-kondisi empiris pendidikan kelas menengah santri, dan lebih jauh memetakan kondisi-kondisi kelas menengah santri tersebut dalam perbandingannya dengan kelompok-kelompok sosial lain yang terdapat di masyarakat. Singkatnya, berdasarkan model konseptual dan definisi yang terstandar tentang kelas menengah santri, orang dapat melakukan sensus terhadap kelas menengah santri, menghitungnya secara 
akurat, dan menggambarkan karakteristik demografis dan ciri-ciri sosio empiris lainnya.

Namun begitu, sebuah ciri demografis tertentu dalam suatu kelompok sosial yang berhubungan dengan tingkat partisipasi politik yang digunakan sebagai indikator bagi variabel peran dalam proses demokratisasi. Ciri dimaksud ialah terdapatnya profesi-profesi tertentu yang secara signifikan berasosiasi dengan peran individu dalam suatu kelompok sosial dalam proses demokratisasi, yaitu dosen dan aktivis LSM. Hal yang menarik untuk dikemukakan di sini ialah bahwa dalam konteks profesi sebagai aktivis LSM, terdapat lebih banyak individu dari kelas menengah santri yang melakoni profesi ini dibandingkan dengan kelompok-kelompok sosial lain. Pada titik ini, keterlibatan kelas menengah santri yang tinggi dalam profesi-profesi yang berasosiasi dengan tingkat partisipasi politik mengukuhkan peran kelas menengah santri dalam proses demokratisasi di Indonesia. Peran ini dikukuhkan dengan temuan survei lain yang menunjukkan bahwa individuindividu dari kelompok kelas menengah santri memiliki sikap yang lebih positif terhadap isu-isu seputar hak-hak kelompok minoritas dibandingkan dengan kelompok-kelompok sosial yang lain.

Temuan terkait variabel-variabel ini menunjukkan bahwa peran individu dari suatu kelompok dalam proses demokratisasi tidak terutama berhubungan dengan posisinya dalam strata sosial ekonomi (apakah individu itu bagian dari kelas atas, kelas bawah, atau kelas menengah) atau latar belakang pendidikan keagamaannya (apakah individu itu santri atau non-santri), tetapi lebih dengan karakteristik demografis (dalam hal ini adalah profesi, yang layak diduga juga terkait dengan tingkat pendidikan formal individu tersebut) dan perspektif ideologis individu dari suatu kelompok sosial dalam menyikapi isuisu seputar keberagaman sosiokultural yang terdapat di masyarakat.

\section{Daftar Pustaka}

Abdillah, Masykuri, 2011, Islam dan Dinamika Sosial Politik di Indonesia, PT Gramedia, Jakarta.

Abdullah, Taufik (ed.), 1988, Agama, Etos Kerja dan Perkembangan Ekonomi, LP3ES, Jakarta.

Abdullah, Taufik \& Karim, M. Rusli, 1989, Metodologi Penelitian Agama: Sebuah Pengantar, Tiara Wacana, Yogyakarta.

Achidsti, Sayfa Auliya, 2015, Kiai dan Pembangunan Institusi Sosial, Pustaka Pelajar, Yogyakarta. 
Ali, Fachry \& Effendi, Bahtiar, 1992, Merambah Jalan Baru Islam: Rekonstruksi Pemikiran Islam Indonesia Masa Orde Baru, Mizan, Bandung.

Anderson, Benedict, 2008, Imagined Communities: Komunitasa-komunitas Terbayang, penerjemah Omi Intan Naomi, INSIST dan Pustaka Pelajar, Yogyakarta.

Barton, Greg, 1999, Gagasan Islam Liberal di Indonesia, penerjemah Nanang Tahqiq, Paramadina, Jakarta.

Boland, B.J., 1971, The Struggle of Islam in Modern Indonesia, The Hague Martinus Nijhoff, Netherlands.

Budiarjo, Mariam, 1998, Partisipasi dan Partai Politik, Gramedia, Jakarta.

Dwiningrum, Siti Irene Astuti, 2011, Desentralisasi dan Partisipasi Masyarakat Dalam Pendidikan, Pustaka Pelajar, Yogyakarta.

Dhofier, Zamakhsyari, 1994, Tradisi Pesantren: Studi Tentang Pandangan Hidup Kyai, LP3ES, Jakarta.

Effendy, Bahtiar, 2009, Islam dan Negara: Transformasi Gagasan dan Praktik Politik Islam di Indonesia, cet. ii, yang diperluas, Paramadina, LSI, dan Prenada Media Group, Jakarta.

Geertz, Clifford, 1976, The Religion of Java, The University of Chicago Press, Chicago and London.

Hadijaya (ed.), 1999, Kelas Menengah Bukan Ratu Adil, Tiara Wacana, Yogyakarta.

Haris, Syamsuddin, 2014, Masalah-masalah Demokrasi dan Kebangsaan Era Reformasi, Yayasan Pustaka Obor Indonesia, Jakarta.

Hasan, Noorhaidi, "Islam di Kota-kota Menengah Indonesia: Kelas Menengah, Gaya, Hidup, dan Demokrasi" dalam Gerry van Klinen dan Ward Berensschot (ed.), In Search Middle Indonesia: Kelas Menengah di Kotakota Menengah, (Jakarta: KITLV-Jakarta dan Yayasan Pustaka Obor Indonesia, 2016), h.215.

Hefner, Robert W, 2001, Civil Islam: Islam dan Demokrtisasi di Indonesia, penerjemah Ahmad Baso, Institut Studi Arus Informasi (ISAI), Jakarta.

Ingleson, John, 2015, Buruh, Serikat, dan Politik: Indonesia pada 1920an 1930an, penerjemah Andi Achdian, CV Marjin Kiri, Serpong.

Jones, Tod, 2015, Kebudayaan dan Kekuasaan di Indonesia: Kebijaklan Budaya Selama Abad Ke-20 Hingga Era Reformasi, penerjemah Edisius Riyadi Terre, Yayasan Obor Indonesia dan KITLV-Jakarta, Jakarta.

Klandersmans, Bert, 2005, Protes dalam Kajian Psikologi Sosial, Penerjemah Helly P. Sutjipto, Pustaka Pelajar, Yogyakarta.

Kuntowijoyo, 1998, Paradigma Islam: Interpretasi Untuk Aksi, Mizan, Bandung. 
Madjid, Nurcholish, 1999, Bilik-bilik Pesantren: Sebuah Potret Perjalanan, Paramadina, Jakarta.

Mas'oed, Mochtar dan MacAndrews, Collin, 1986, Perbandingan Sistem Politik, Universitas Gajahmada, Yogyakarta.

Mujani, Saiful, 2007, Muslim Demokrat: Islam, Budaya Demokrasi, dan Partisipasi Politik di Indonesia Pasca-Orde Baru, Gramedia Pustaka Utama, Jakarta.

Mulkhan, Abdul Munir, 1992, Runtuhnya Mitos Politik Santri, Sipress, Yogyakarta.

Noer, Deliar, 1988, Gerakan Modern Islam di Indonesia 1900-1942, LP3ES, Jakarta.

Rahardjo, M. Dawam (ed.), 1975, Pesantren dan Pembaharuan, LP3ES, Jakarta. Sarwono, Sarlito Wirawan, dkk, 2009, Psikologi Sosial, Salemba Humanika, Jakarta.

Singarimbun, Masri \& Effendi, Sofian (ed.), 1995, Metode Penelitian Survai, LP3ES, Jakarta.

Tanter, Richard \& Young, Kenneth, 1993, Politik Kelas Menengah Indonesia, penerjemah Nur Imam Subono, LP3ES, Jakarta.

Wertheim, W.F., 1956, Indonesian Society in Transition, Sumur Bandung, Bandung.

Woodward, Mark R. (ed.), 1998, Jalan Baru Islam: Memetakan Paradigma Mutakhir Islam Indonesia, penerjemah Ihsan Ali-Fauzi, Mizan, Bandung.

Yuswohady, 2015, Marketing to The Middle Class Muslim, PT Gramedia, Jakarta.

\section{Catatan Akhir}

1. Lipset, Seymour Martin. 1959. "Some Social Requisites of Democracy: Economic Development and Political Legitimacy." The American Political Science Review 53 (1): 69105.

2. Lipset, Seymour Martin, Political Man: The Social Bases of Politics, (Johns Hopkins University Press, 1981).

3. Nie, Norman H., Bingham Powell, and Kenneth Prewitt, 1969, "Social Structure and Political Participation: Development Relationship”, American Political Science Review, , 2 bagian, vol 62 no. 2 dan 3: 361 - 76 dan 808 - 832 .

4. Dahl, R.A, 1971, Polyarch: Participation and Opposition, (New Haven: Yale University Press 
5. Ronald M. Glassman, The Middle Class and Democracy in Socio-Historical Perspective,

6. Tamio Hattori, "Introduction: The Emergence of the Asian Middle Classes and Their Characteristics", dalam Jurnal The Developing Economies XLI-2 (June 2003): 129-39

7. Bruce J Dickson, "China's Middle Class : An Agent of the Status Quo or a Force for Change?” Dalam Cheng Li, China's Emerging Middle Class, 2010, Brookings Institution Press, Washington, D.C, h. 245.

8. Mariam Budiarjo, Partisipasi dan Partai Politik, (Jakarta: Gramedia, 1998), h. 2.

9. Siti Irene Astuti Dwiningrum, Desentralisasi dan Partisipasi Masyarakat Dalam Pendidikan (Yogyakarta: Pustaka Pelajar, 2011), h. 61-63.

10. Merphin Panjaitan, Gerakan Warga Negara Menuju Demokrasi, Jakarta, 2001, h. 8

11. Mochtar Mas'oed dan Collin MacAndrews, Perbandingan Sistem Politik (Yogyakarta: Universitas Gajahmada,1986), hal 40-50.

12. Eriyanto, "Golput Dalam Pilkada", Kajian Bulanan LSI Edisi 05 September 2007, dikutip dari www.lsi.co.id

13. The World Bank, "Perkembangan Triwulan Perekonomian di Indonesia." World Bank, 2010. h. 44

14. Asian Development Bank, 2010, "The Rise of Asia's Middle Class", dalam Key Indicators for Asia and the Pacific 2010, Manila.

15. Americasquartely.org, Assessing The Impact of The New Middle Class on Plitic and Democracy. Link: http://americasquarterly.org/charticles/charticle new middle class.html (diakses 3 September 2015)

16. Eteng Uwe dan Opeke R. O, "Information Accessibility and Use as Correlates of Women Political Participation in the Niger Delta Region of Nigeria." Psychology and Behavioral Sciences 2015; 4(1): 5-17.

17. Eteng Uwe dan Opeke R. O, "Information Accessibility" 4(1): 5-17.

18. Tom Christensen and Per Lagreid, "Trust in Government - the Significance of Attitudes Towards Democracy, the Public Sector and Public Sector Reforms." Stein Rokkan Centre for Social Studies-Bergen University Research Foundation, 2013. h. 12.

19. Sang Ok Choi dan Sunhyuk Kim, "An Exploratory Model of Antecedents and Consequences of Public Trust in Government." h8, https://iiastrust.files.wordpress.com/2012/07/an-exploratory-model-of-antecedents-andconsequences-of-public-trust-in-government.pdf (diakses 2 September 2015).

20. Sang Ok Choi dan Sunhyuk Kim, "An Exploratory” h. 4.

21. Sang Ok Choi dan Sunhyuk Kim, "An Exploratory" h. 8.

22. Soebagio, "Distorsi dalam Transisi Demokrasi di Indonesia." Jurnal Makara, Vol. 13, No. 2, Desember 2009: 111-116, h. 114.

23. Otho H. Hadi, "Peran Masyarakat Sipil dalam Proses Demokratisasi." Jurnal Makara, Vol. 14, No. 2, Desember 2010:117-129. h. 126.

24. Dana R. Carney, dkk., "The Secret Lives of Liberals and Conservatives: Personality Profiles, Interaction Styles, and the Things They Leave Behind." Political Psychology, Vol. 29, No. 6, 2008. h. 836

25. Sarlito W., dkk., Psikologi Sosial (Jakarta: Salemba Humanika, 2009). jilid I, h. 247. 
26. Bert Klandersmans, Protes dalam Kajian Psikologi Sosial, Penerjemah Helly P. Sutjipto, (Yogyakarta; Pustaka Pelajar, 2005), h. 368.

27. Bert Klandersmans, Protes dalam Kajian Psikologi Sosial, h. 369.,

28. The World Bank, "Perkembangan Triwulan Perekonomian di Indonesia." World Bank, 2010. h. 44.

29. Zamakhsyari Dzofier, Tradisi Pesantren, Studi Tentang Pandangan Hidup Kiai (Jakarta: LP3ES, 1982), hlm. 18

30. Nurcholish Madjid, Bilik-bilik Pesantren: Sebuah Potret Perjalanan (Jakarta: Paramadina.1999), h. 19-20

31. Zamakhsyari Dzofier, Tradisi Pesantren, h. 52.

32. Robert W Hefner, Civil Islam: Islam dan Demokratisasi di Indonesia, penerjemah Ahmad Baso (Jakarta: Institut Arsu Studi Informasi (IASI), 2001) h. 21.

33. Kuntowijoyo. Paradigma Islam: Interpretasi Untuk Aksi. (Bandung: Mizan, 1991). h. 37078. 